JAIME W. HUNT

The University of Newcastle

jaime.hunt@newcastle.edu.au

\title{
LEXICAL HYBRIDIZATION OF ENGLISH AND GERMAN ELEMENTS: A COMPARISON BETWEEN SPOKEN GERMAN AND THE LANGUAGE OF THE GERMAN NEWSMAGAZINE DER SPIEGEL
}

Keywords: anglicisms, spoken German, Der Spiegel, lexical hybridization, loanblends

\begin{abstract}
The influence of English on German has resulted in not only the direct importation of a vast number of English loanwords but also their hybridization with native German elements. The most common types of language hybrids, or loanblends, using Haugen's (1950) terminology, in German include blended compounds containing one element from the source language and another from the receptor language (e.g. Businessbereich 'business sector' and Krafttraining 'strength training') in addition to blended derivations where autochthonous derivational affixes are attached to English stems (e.g. sportlich 'sporty' and rumsurfen 'to surf around'). This paper contributes to the investigation of how, and to what extent, English elements become morphologically embedded into German by analyzing the English-German hybrid formations from a corpus of everyday spoken German (42,429 types and 1,280,773 tokens) and the texts appearing in the Spiegel newsmagazine from the year 2000 (287,301 types and 5,202,583 tokens). General findings indicate that the most common form of hybridization is the compounding of English specifiers with German heads and much less the attachment of German morphemes (both derivational affixes and semi-affixes) to English stems in both spoken and written texts. These forms of hybridization demonstrate both the productive word formation processes of German as well as its contact-induced lexical enrichment beyond the mere direct borrowing of loanwords. However, when analyzed separately, the most frequently-occurring specifiers and heads were anglicisms. A slight preference for German affixation (affixes and semi-affixes) was found in the spoken corpus with the Spiegel corpus containing more English semi-affixes.
\end{abstract}




\section{Acknowledgements}

Many thanks to Prof. Dr. Alexander Onysko at the Alpen-Adria University, Klagenfurt, Austria, for sharing his list of anglicisms found in all the editions of Der Spiegel from the year 2000. My appreciation also goes to the Institut für deutsche Sprache in Mannheim for sharing transcriptions of the Deutsch Heute corpus, and to the Bayerisches Archiv für Sprachsignale at the Ludwig Maximilian University in Munich for providing transcriptions of the Regional Variants of German 1 and Hempels' Sofa corpora.

\section{Lexical hybridization as a result of language contact}

Written German, whether appearing in the print media, in advertisements, or on shop signs, is the most widely used source of data for studies of anglicisms (e.g. Langer 1996; Plümer 2000; Götzeler 2008), and perhaps no other media publication has received as much attention as the German newsmagazine Der Spiegel. Authors such as Carstensen (1965), Yang (1990), Onysko (2007), and more recently Knospe (2014), have used this as a data source to provide detailed analyses of the occurrence of anglicisms in German. Such an item of the print media provides an accessible data set reflecting modern language use on a wide variety of topics and is highly suitable for corpus analysis. However, it must be noted that the language of the press is carefully crafted, highly edited, and, in cases such as the Spiegel, known for its stylized and innovative use of language (Onysko 2007). What many may consider "true" or "genuine" German, that is, everyday spontaneous spoken language, is underrepresented in studies of anglicisms in German. This study aims to address this issue by comparing two forms of language, namely that appearing in a corpus of spoken German and of the newsmagazine Der Spiegel by focussing on the phenomenon of lexical hybridization.

In research on anglicisms, hybridization is viewed at various levels, ranging from the affixation of native morphemes to non-native stems, through the compounding of native and non-native free morphemes, and on to textual and whole-language levels. In his study on English and Norwegian in the United States, Haugen (1950: 214) refers to hybrids as the result of where "... only a part of the phonemic shape has been imported, while a native portion has been substituted for the rest”. Within this category, he further defines blended derivations, where native derivational elements are attached to foreign bases. In the context of German, this results in derived hybrid forms such as sportlich 'sporty' and rockig from 'rocky' (where the English - $y$ suffix is replaced by its German equivalent), along with ausloggen 'to log out' (where the prefix aus-'out' is attached to the English stem $\log$ with the additional of the infinitive suffix -en). Haugen (1950: 215) also excludes from this category examples of the affixation of inflectional morphemes to foreign stems because "they do not affect the grammatical structure of a word but are necessary and therefore non-distinctive accompaniments of its use in the sentence". Furthermore, words with derivational 
affixes appear in dictionaries and derivational affixes affect meaning of the stems they are attached to. However, words with inflectional affixes do not appear in dictionaries and inflectional morphemes do not affect meaning. Thus, unlike some authors investigating hybridization (e.g. Burmasova 2010; Scherling 2013), inflectional morphology shall not be considered in this analysis of lexical hybridization.

Blended compounds involve a combination of free morphemes, one from the source language and the other from the receptor language. In German, this process results in compounds such as e.g. Businessbereich 'business sector' and Krafttraining 'strength training', and Schulstress 'school stress'.

On the hybridization spectrum between blended derivations and blended compounds sits semi-affixation. Somewhat controversial, semi-affixes, otherwise known as affixoids (Booij, Hüning 2014), behave similarly to derivational affixes but are free morphemes with an unbound meaning. Examples can be seen in Haupthobby 'main hobby', where haupt- means 'head' as a free morpheme but 'main' as a bound morpheme. Similarly in computermäßig 'by computer, electronically', -mäßig can mean '-like/-wise' as an affix but 'moderate' or 'mediocre' when used as a lexical morpheme.

Following Haugen (1950), some authors (e.g. Busse 20o1; Pulcini, Furiassi, González 2012) present a distinction between types of hybrid compounds. They include a division between loanblends and hybrid creations based on whether there is an English model available for the hybrid. They consider loanblends to have an existing model in the source language, whereas hybrid creations do not. However, the existence of an English model is not always easily determined, especially because English and German have similar word formation processes, and thus, this distinction shall not be considered here. In contrast to this narrower focus, SanchezStockhammer (2012) provides a much broader classification of hybridization. She proposes that hybridization should be considered as ranging from the phonemic and morphological levels through to text types, whole languages, and communication in general. Such a broad classification is beyond the scope of this analysis.

In order to guide the following comparison of English-German hybrid forms appearing in spoken German and the Spiegel, the following research questions were devised:

1. Is there a demonstrated preference to borrow English lexemes directly into German or form new ones by hybridizing English and German elements?

2. Which hybrid formations occur and how frequently do they appear?

3. In hybrid compounds, do anglicisms appear more frequently as specifiers or heads?

4. What are the most productive components in hybrid compounds?

\section{Preparing the spoken and written data}

To investigate the lexical hybridization of English and German elements, two data sets were sourced. The first is from three corpora of everyday spoken German compiled in the late 1990 s to the early 2000 s which were combined into one large corpus 
totalling 42,429 types and 1,280,773 tokens. The speech samples in this combined corpus were obtained from the Bayerisches Archiv für Sprachsignale (Bavarian Archive for Speech Signals) and the Institut für deutsche Sprache (Institute for German Language), and were provided by 4,700 participants across Germany, Austria, Liechtenstein, Luxembourg, and the areas in Switzerland, Belgium, and Italy where German is spoken. The participants spoke about their activities either at work or at home, in addition to other general topics such as their hobbies and leisure time.

Once the corpora were combined, utterances from participants outside Germany were removed to allow for a greater comparison with the Spiegel published in Germany. The three original corpora in this study were not complied for the purposes of anglicism research; however, because there was not an emphasis on English-German lexical contact at the time of data collection, there should be a lack of bias towards anglicisms in the corpora.

All possible anglicisms in the combined corpus were manually identified from words lists using Görlach’s (1994: 224) definition of an anglicism as “a word or idiom that is recognizably English in its form (spelling, pronunciation, morphology, or at least one of the three)". The word list providing the data for the Spiegel analysis was compiled by Prof. Dr Alexander Onysko, who had analyzed the anglicisms appearing in the 52 editions of the Spiegel from the year 2000. The number of types and tokens for each corpus appears in Table 1.

\begin{tabular}{ccccc} 
Corpus & Total types & Total tokens & Anglicism types & Anglicism tokens \\
\hline Spoken & 42,429 & $1,280,773$ & $2,095(4.94 \%)$ & $7,319(0.57 \%)$ \\
Spiegel* & 287,301 & $5,202,583$ & $16,663(5.80 \%)$ & $57,075(1.08 \%)$ \\
\hline
\end{tabular}

Table 1. Number of anglicism types per corpus

* From Onysko (2007)

Then, those hybrids formed by derivation, compounding, and semi-affixation (as indicated in Table 2) were identified and extracted from both word lists. Proper nouns and codeswitches were also excluded.

During this process, several issues required consideration. The first was the affixation of the native feminine suffix -in to anglicism stems. Although it is a derivational affix, -in is attached only to the native suffixes -er or -ist, and in this way, can be applied to any agentive noun. In this way, -in is so highly productive it does not necessitate discussion as it says little about the incorporation of anglicisms into German. Thus, it was excluded from this analysis. The second issue arose due to the morphological similarities between English and German. For example, agentive nouns in both languages often take the -er suffix. This means that it is conceivable that nouns such as Discounter could have entered German via one of two processes: (1) direct borrowing of the single unit Discounter from English, or (2) hybridization between the borrowed stem Discount and the native German -er suffix. Such cases make it difficult, if not impossible, to determine the origin of these loans. However, 


\begin{tabular}{ll}
$\begin{array}{l}\text { Compounding } \\
\text { English specifier, German head } \\
\text { German specifier, English head }\end{array}$ & $\begin{array}{l}\text { Computer-raum 'computer room' } \\
\text { Heim-computer 'home computer' } \\
\text { English word inside multi-element word } \\
\text { German word inside multi-element word } \\
\text { Internet-Reise-boom 'internet travel boom' }\end{array}$ \\
$\begin{array}{l}\text { Derivation } \\
\text { English stem, German derivational suffix }\end{array}$ & $\begin{array}{l}\text { stress-ig 'stressful, stress' } \\
\text { rum-surfen 'to surf around' }\end{array}$ \\
$\begin{array}{l}\text { Semi-affixation } \\
\text { German semi-prefix, English stem }\end{array}$ & $\begin{array}{l}\text { Neben-job 'side job' } \\
\text { English stem, German semi-suffix }\end{array}$ \\
$\begin{array}{l}\text { English semi-prefix, German stem } \\
\text { German stem, Engligh 'flatrate-like' }\end{array}$ \\
\hline
\end{tabular}

Table 2. Hybrid types extracted from spoken and Spiegel corpora for analysis

if such instances appeared in the Oxford English dictionary online in their full form, they were considered direct borrowings and thus excluded from this analysis.

In German, the heads of compound nouns are the right-most element. For example, the head of Babysprache 'baby language, baby talk' is -sprache. For the closer analysis of hybrid compounds each group of hybrid compounds was divided into separate lists of specifiers and heads and then analyzed separately again into anglicisms and German elements. There are a number of items in the data sets where the head is also a compound containing an anglicism, e.g. Kinostarttermin 'cinema release date'. This has three elements kino - start - termin 'cinema - start - date' but is it divisible as Kino-Starttermin, where Starttermin is the head, which is itself a compound with an English modifier and a German head. Hence, this was classified as such. To ensure that a compound contained a semi-affix and not an unbound specifier or head, the Duden online dictionary of German was used to determine whether the affix in question appears as both an affix and a free morpheme with related meaning. The resulting data sets of specifiers and heads were used to create a word frequency list (two each - heads and specifiers - for each corpus) giving not only types but also tokens within each data set.

\section{Analyzing the data}

\section{General results}

Table 3 shows the first of the results obtained using the above-mentioned methods of data extraction. It appears that there is a preference to borrow anglicisms directly in the spoken corpus, with just over $37 \%$ of all anglicism types in the spoken data set being hybrid formations. In comparison, slightly more than $50 \%$ of anglicism types 
in the Spiegel corpus are hybrid formations. The portion of hybrid formations when compared to the overall types (both native and non-native) is higher in the Spiegel corpus than in the spoken.

Both data sets contain similar proportions of nouns and adverbs. However, hybridized verbs and adjectives constitute a higher portion of the word classes in the spoken data set, as shown in Table 4.

\begin{tabular}{lccc} 
Corpus & Total hybrid types & $\begin{array}{c}\text { As portion of angli- } \\
\text { cism types }\end{array}$ & $\begin{array}{c}\text { As portion of cor- } \\
\text { pus types }\end{array}$ \\
\hline Spoken & 739 & $37.25 \%$ & $1.74 \%$ \\
Spiegel & 8,551 & $51.32 \%$ & $2.98 \%$ \\
\hline
\end{tabular}

Table 3. Hybrid anglicism types as portion of each corpus

* From Onysko (2007)

\begin{tabular}{lccccc} 
Corpus & Total & Noun & Verb & \multicolumn{1}{c}{ Adjective } & \multicolumn{1}{c}{ Adverb } \\
\hline Spoken & 739 & $685(92.69 \%)$ & $28(3.79 \%)$ & $19(2.57 \%)$ & $7(<1.00 \%)$ \\
Spiegel & 8,551 & $8370(97.88 \%)$ & $45(<1.00 \%)$ & $125(1.46 \%)$ & $11(<1.00 \%)$ \\
\hline
\end{tabular}

Table 4. Hybrid word class types per corpus

\section{Compounding}

Analyzing each data set using the categories expressed in Table 2 provides the descriptive statistical results presented in Table 5 and Table 6. By far, the most prevalent hybrid type are the compound noun forms, constituting $88.9 \%$ of the spoken data set and $91 \%$ of the Spiegel data set. Similar proportions of each data set belong to German-headed compounds (just over half of all types) and English-headed compounds (just over one-third of all types).

In hybrid compounds in both data sets, it appears that anglicisms appear most frequently as specifiers to German heads. Although this may indicate that the main function of anglicisms in the specifier position is simply to add specificity to native heads, it must be considered within context. Nearly $77 \%$ of the 393 specifier types in the spoken corpus and 60\% of the 2335 specifier types in the Spiegel corpus appear only once. Most of those consist of autochthonous terms. This then indicates that a much smaller proportion of these hybrids have few, but highly repeated anglicisms in the specifier position of compounds (see Table 7). The specifiers computer and internet feature in the most frequent specifiers in both data sets.

Similar to the analysis of specifiers above, at first glance it may appear that anglicisms dominate the category of heads of hybrid compounds. However, considering that $73 \%$ of the 356 head types in the spoken corpus and just over $60 \%$ of the 


\begin{tabular}{|c|c|c|c|c|c|c|}
\hline Hybrid & Noun & Verb & $\begin{array}{l}\text { Adjec- } \\
\text { tive }\end{array}$ & Adverb & Total & $\begin{array}{l}\% \text { of data } \\
\text { set types }\end{array}$ \\
\hline E-G & 391 & & 4 & 1 & 396 & 53.59 \\
\hline G-E & 245 & 1 & & & 246 & 33.31 \\
\hline G-E-G & 17 & & & & 17 & 2.30 \\
\hline Total compounds & 653 & 1 & 4 & 1 & 659 & 89.17 \\
\hline G suffix & 14 & & 7 & 1 & 22 & 2.98 \\
\hline G prefix & & 27 & 2 & & 29 & 3.92 \\
\hline Total German affixes & 14 & 27 & 9 & 1 & 51 & 6.90 \\
\hline G semi-prefix & 8 & & & & 8 & 1.08 \\
\hline G semi-suffix & 4 & & 6 & 5 & 15 & 2.03 \\
\hline E semi-prefix & 4 & & & & 4 & $<1.00$ \\
\hline E semi-suffix & 2 & & & & 2 & $<1.00$ \\
\hline Total semi-affixes & 18 & & 6 & 5 & 29 & 3.92 \\
\hline Total types & 685 & 28 & 19 & 7 & 739 & 100 \\
\hline$\%$ of types & $92.69 \%$ & $3.79 \%$ & $2.57 \%$ & $<1.00 \%$ & $100 \%$ & \\
\hline
\end{tabular}

\section{Key}

\section{Compounds}

$E-G$

$G-E$

$G-E-G$

$E-G-E$

English specifier, German head

German specifier, English head

English word inside multi-element word

German word inside multi-element word

\section{Derivations}

G suffix

Gprefix

English stem, German derivational suffix

German derivational prefix, English stem

\section{Semi-affixes}

G semi-prefix

G semi-suffix

German semi-prefix, English stem

English stem, German semi-suffix

E semi-prefix

English semi-prefix, German stem

E semi-suffix

German stem, English semi-suffix

Table 5. Hybrid types in the combined spoken corpus 


\begin{tabular}{|c|c|c|c|c|c|c|}
\hline Hybrid & Noun & Verb & $\begin{array}{l}\text { Adjec- } \\
\text { tive }\end{array}$ & Adverb & Total & $\begin{array}{l}\% \text { of data } \\
\text { set types }\end{array}$ \\
\hline E-G & 4780 & & 39 & 1 & 4820 & 56.37 \\
\hline G-E & 2860 & 6 & 8 & & 2874 & 33.59 \\
\hline G-E-G & 83 & & & & 83 & $<1.00$ \\
\hline E-G-E & 9 & & & & 9 & $<1.00$ \\
\hline Total compounds & 7732 & 6 & 47 & 1 & 7786 & 91.05 \\
\hline G suffix & 49 & & 25 & 1 & 75 & $<1.00$ \\
\hline G prefix & 38 & 38 & 14 & 1 & 91 & 1.06 \\
\hline Total German affixes & 87 & 38 & 39 & 2 & 166 & 2.08 \\
\hline G semi-prefix & 89 & & 2 & & 91 & 1.06 \\
\hline G semi-suffix & 40 & & 34 & 8 & 82 & $<1.00$ \\
\hline E semi-prefix & 405 & 1 & 3 & & 409 & 4.78 \\
\hline E semi-suffix & 17 & & & & 17 & $<1.00$ \\
\hline Total semi-affixes & 551 & 1 & 39 & 8 & 599 & 7.00 \\
\hline Total types & 8370 & 45 & 125 & 11 & 8551 & 100 \\
\hline$\%$ of types & $97.90 \%$ & $<1.00 \%$ & $1.45 \%$ & $<1.00 \%$ & $100 \%$ & \\
\hline
\end{tabular}

Table 6. Hybrid types in the Spiegel corpus See above Table 5 for key

2634 head types in the Spiegel corpora are unique, appearing only once, and that the majority of these are native terms, it can also be concluded that the few anglicisms that appear as heads do so very frequently (see Table 8). The anglicisms film and test appear among the most frequent heads in hybrid nouns in both corpora.

The preponderance of elements within the semantic fields of technology and lifestyle, e.g. sport, computer, internet, film, and show in both specifier and head positions is also worth noting.

\section{Derivational forms}

There were 51 instances of English stems combined with German derivational affixes in the spoken corpus, with 166 appearing in the Spiegel corpus. This equates to $6.90 \%$ and $2.08 \%$ of all hybrid types in each corpus respectively. They appear to be evenly distributed between suffixes and prefixes in each corpus, with differences occurring regarding their distribution among word classes. 


\begin{tabular}{lcclc}
\multicolumn{1}{c}{ Corpus } & Rank & Types & \multicolumn{1}{c}{ Specifier } & \% of types \\
\hline & 1 & 32 & sport & 8.14 \\
Spoken corpus & 2 & 29 & computer & 7.38 \\
Types: 393 & 3 & 14 & internet & 3.56 \\
Tokens: 664 & 4 & 9 & park & 2.29 \\
& 5 & 8 & party & 2.04 \\
\hline & 1 & 283 & internet & 12.12 \\
Spiegel corpus & 2 & 243 & computer & 10.41 \\
Types: 2335 & 3 & 199 & film & 8.52 \\
Tokens: 8214 & 4 & 131 & hightech & 5.61 \\
& 5 & 103 & test & 4.41 \\
\hline
\end{tabular}

Table 7. Most frequent specifiers in hybrid compounds

\begin{tabular}{lcclc}
\multicolumn{1}{c}{ Corpus } & Rank & Types & Head & \% of types \\
\hline & 1 & 16 & fan & 4.49 \\
Spoken corpus & 2 & 16 & film & 4.49 \\
Types: 356 & 3 & 16 & test & 4.49 \\
Tokens: 643 & 4 & 12 & computer & 3.37 \\
& 5 & 12 & job & 3.37 \\
& 1 & 118 & film & 4.48 \\
Spiegel corpus & 2 & 110 & manager & 4.18 \\
Types: 2634 & 3 & 108 & test & 4.10 \\
Tokens: 7717 & 4 & 85 & team & 3.23 \\
& 5 & 79 & show & 3.00 \\
\hline
\end{tabular}

Table 8. Most frequent heads in hybrid compounds 
In the spoken corpus, 14 types of German prefixes appeared. They were attached to verbs primarily in past participle form (e.g. durch-gecheckt 'checked through', ein-geloggt 'logged in', and weiter-gesurft 'surfed (on) further'), one deverbal adjective (rüber-gestresst 'overstressed') and one adjective (un-cool ' 'uncool'). Thirteen German suffix types were attached to 21 English stems to create fourteen nouns (e.g. Partner-schaft 'partnership', Snob-ismus 'snobbism', and Test-ung 'test, testing'), seven adjectives (e.g. humor-istisch 'humorous', stress-ig 'stressful', and sprinter-isch 'sprinter-y, sprinter-like') and one adverb (hobby-haft 'hobby-like, as a hobby').

In the Spiegel corpus, the distribution of derivational hybrids differs somewhat. The main difference is that, unlike the spoken corpus, the Spiegel corpus contains not only hybrid nouns with German prefixes on English stems (e.g. Fehl-start 'false start', Mikro-trend 'micro-trend', and Ur-Girl 'prehistoric/primitive girl') but also a similar number of them are verbs with derivational prefixes (e.g. aus-geknockt 'knocked out, herauf-jazzen 'to jazz up', and herunter-sprintet 'sprinted down'). Similar to the spoken corpus, the distribution of German suffixes in the Spiegel corpus occurs mostly on nouns (e.g. Deal-erei 'dealing', Film-ung 'filming', and Lobby-ismus 'lobbyism'), without about half of that number on adjectives (e.g. clown-esk 'clown-like', spac-ig 'spacey', and recycle-bar 'recyclable').

\section{Forms with semi-affixation}

Very few semi-affixes occurred in the spoken corpus in comparison to the Spiegel corpus. Table 9 shows that the German haupt-and the English hobby-appear in both data sets. Although there is little difference between the instances of semiprefixes in the spoken corpus, it is clear that the most common semi-prefixes in the Spiegel corpus are anglicisms and appear much more frequently than their German counterparts do.

Table 10 shows that the English -freak is the only semi-suffix appearing in both spoken and Spiegel corpora. No other semi-suffix is shared by the data sets.

\section{Discussion}

The comparison of hybrids appearing in the spoken and the Spiegel corpora reveals that hybridization of English and German elements in spoken language occurs less frequently than in the news magazine. The majority (nearly 63\%) of anglicisms in the spoken corpus are direct borrowings, with the remainder consisting of hybrid formations. This is similar to the findings reported in Glahn's (2002) analysis of spoken German on television, despite a good deal of his speech data having been first written or scripted. In contrast, the Spiegel data set contains

Although uncool may be considered a direct loan, where the un-is semantically identical in both English and German forms, it is phonologically German (Onysko 2007). 


\begin{tabular}{lcrll} 
Corpus & Rank & Types & Semi-prefix & \multicolumn{1}{c}{ Examples } \\
\hline \multirow{5}{*}{ Spoken corpus } & 1 & 2 & Haupt- & Haupthobby 'main hobby' \\
& 2 & 1 & Neben- & Nebenjob 'side job' \\
& 1 & 3 & Hobby- & Hobby-Gärtner 'hobby gardener' \\
& 2 & 1 & No-Name- & No-Name Firmen 'no-name firms' \\
\hline & 1 & 25 & polit- & polit-junkies 'political junkies' \\
& 2 & 9 & riesen- & Riesenflop 'giant flop' \\
& 3 & 8 & haupt- & Hauptjob 'main job' \\
& 4 & 8 & spitzen- & Spitzendesigner 'top-designer' \\
& 5 & 7 & alt- & Altrocker 'former rocker' \\
& 6 & 7 & öko- & Öko-Freaks 'eco-freaks' \\
& 1 & 209 & online- & Online-Fahrt 'online trip' \\
& 2 & 63 & cyber- & Cyber-Traum 'cyber-dream' \\
& 3 & 61 & top- & Top-Gastarbeiter 'top host' \\
& 4 & 49 & hobby- & Hobbyforscher 'hobby researcher' \\
& 5 & 11 & e- & E-Notizbuch 'e(lectronic)-notebook' \\
\hline
\end{tabular}

Table 9. Most frequent semi-prefixes

Note: German semi-prefixes appear in italics

\begin{tabular}{|c|c|c|c|c|}
\hline Corpus & Rank & Types & Semi-suffix & Examples \\
\hline \multirow{4}{*}{ Spoken corpus } & 1 & 10 & -mäßig & $\begin{array}{l}\text { computermäßig 'by computer/ } \\
\text { electronically' }\end{array}$ \\
\hline & 2 & 2 & -sache & Teddysachen 'teddy things' \\
\hline & 3 & 2 & $-z e u g$ & Squashzeug 'squash equipment/gear' \\
\hline & 1 & 2 & -freak & Mäusefreak 'mouse-freak' \\
\hline \multirow{7}{*}{ Spiegel corpus } & 1 & 11 & $-f r a u$ & Powerfrau 'power woman' \\
\hline & 2 & 7 & -leute & PR-Leute 'PR-people' \\
\hline & 3 & 7 & $-m a n n$ & Computermann 'computer man' \\
\hline & 4 & 7 & -trächtig & imageträchtig 'image-heavy’ \\
\hline & 5 & 6 & -fähig & teamfähig 'team-minded' \\
\hline & 6 & 6 & -tauglich & covertauglich 'cover-worthy' \\
\hline & 1 & 17 & -freak & Flugzeugfreak 'aeroplane freak' \\
\hline
\end{tabular}

Table 10. Most-frequent semi-suffixes

Note: German semi-prefixes appear in italics 
a roughly equal number of anglicisms that were borrowed directly or hybridized with German elements.

Overall, the above analyses confirm that the most common form of hybridization in German is that of compounding. Both the spoken and Spiegel data sets contain a similar number of hybrid compounds (approximately 90\% of all hybrid forms), reflecting previous studies by Glahn (2002) and Dargiewicz (2013), where hybrid compounds constitute $98.8 \%$ and $93 \%$ of their data sets respectively. The most common hybrid compounds are combinations of English specifiers and German heads (more than half of all hybrid types in both data sets), whereas fewer (approximately one-third of all data set types) are compounds with English heads. Similarly, Dargiewicz (2013) found that nearly $57 \%$ of her hybrid data set types were compounds with German heads. This preference for English specification on German-headed compounds, according to Burmasova (2010), is due to uncertainty among German speakers in how to inflect anglicism heads. However, as anglicisms are routinely inflected without issue by native speakers (Busse, Görlach 2002; Götzeler 2008; Moraldo 2008; Onysko 2009), it is more likely that anglicisms appear more frequently as specifiers than heads because they are used to provide additional nuances and vocabulary enrichment to the pre-existing categories represented by the German heads. Thus, adding specificity to, or expanding, semantic categories. Surprisingly, these findings contrast with those of Glahn (2002), who reports that nearly 58\% of his spoken hybrid compounds taken from German television have English heads, and $43 \%$ have German heads.

When considering the different components of hybrid compounds in both data sets separately, the most surprising finding is that in both data sets, the five most frequent specifiers and heads in hybrid compounds are anglicisms. However, both data sets have a very high number of hybrid compound forms appearing once only in each data set (hapax legomana constitute over three-quarters of the spoken data set's hybrid compounds and 60\% of those in the Spiegel data set). Although at first it may appear that anglicisms are numerous, there is much greater variety in the native elements in compounds.

The most common anglicisms in either specifier or head position of hybrid compounds (and semi-prefixes in the Spiegel corpus) belong to the semantic fields described in Steffens (2003: 5) as Spaßgesellschaft 'leisure society' and technology. This aligns with previous studies (e.g. Clyne 1995; Glahn 2002; Grote 2002; Schäfer 2002; Augustyn 2006) noting that anglicisms appear most frequently in these two semantic fields.

With regard to semi-affixation, the spoken corpus contains relatively few semiaffixes of either English or German origin. In comparison, the Spiegel corpus contains a greater number of semi-affixes overall, but the most dominant feature is the comparatively high number of types and tokens of English semi-prefixes. Semantically, the most commonly-occurring semi-affixes in the Spiegel corpus also belong to the fields of Spaßgesellschaft 'leisure society' (2003) as well as technical terminology, as do the elements in compounds mentioned above. Only one English semi-suffix, -freak, referring to a person who shows excessive enthusiasm for something, appeared in each of the corpora. 


\section{Conclusion}

The number of hybrids in German (especially hybrid compound nouns - the result of the most productive word formation process in German) reflects the ability of German to integrate foreign elements into its morphological system. The differences in lexical hybridization patterns between the spoken corpus and the Spiegel corpus shown here are surprisingly minor. It was expected that the everyday language of the spoken corpus, transcribed from interviews with participants discussing general topics such as hobbies, daily activities, and leisure time, would yield different results than that of Spiegel, with its greater variety of topics ranging from the political, technical, and social, presented in the sophisticated style of a highly edited newsmagazine renowned for its stylistic innovation and preponderance of anglicisms. Despite these differences in text types, no major differences between the two corpora are apparent at the level of lexical hybridization.

\section{References}

Augustyn P. 2006. The seductive aesthetics of globalization: Semiotic implications of anglicisms in German. - Gardt A., Hüppauf B. (eds.). Globalization and the future of German: With a select bibliography. Berlin: 307-318.

Booij G., Hüning M. 2014. Affixoids and constructional idioms. - Boogaart R., Colleman T., Rutten G. (eds.). Extending the scope of construction-based grammar 2014. Berlin: 77-105.

Burmasova S. 2010. Empirische Untersuchungen der Anglizismen im Deutschen am Material der Zeitung Die Welt (Jahrgänge 1994 und 2004). Bamberg.

Busse U. 2001. Typen von Anglizismen: von der heilago geist bis Extremsparing - aufgezeigt anhand ausgewählter lexikographischer Kategorisierungen. - Stickel G. (ed.). Neues und Femdes im deutschen Wortschatz: aktueller lexikalischer Wandel. [= Jahrbuch 2000, Institut für deutsche Sprache]. Berlin, New York: 131-155.

Busse U., Görlach M. 2002. German. - Görlach M. (ed.). English in Europe 2002. New York: 13-36.

Carstensen B. 1965. Englische Einflüsse auf die deutsche Sprache nach 1945. Heidelberg.

Clyne M. 1995. The German language in a changing Europe. Cambridge.

Dargiewicz A. 2013. Fremde Elemente in Wortbildungen des Deutschen: Zu Hybridbildungen in der deutschen Gegenwartssprache am Beispiel einer raumgebundenen Untersuchung in der Universitäts- und Hansestadt Greifswald. Frankfurt am Main.

Glahn R. 2002. Der Einfluß des Englischen auf gesprochene deutsche Gegenwartssprache: eine Analyse öffentlich gesprochener Sprache am Beispiel von „Fernsehdeutsch“. Frankfurt am Main.

Görlach M. 1994. A usage dictionary of anglicisms in selected European languages. - International Journal of Lexicography 7: 223-246.

Götzeler C. 2008. Anglizismen in der Pressesprache. Alte und neue Bundesländer im Vergleich. Bremen.

Grote A. 2002. Entlehnung - Übersetzung - Vernetzung: Entlehnung als übersetzungsbezogenes Phänomen am Beispiel der internetspezifischen Computerfachsprache. Frankfurt am Main.

Haugen E. 1950. The analysis of linguistic borrowing. - Language 26: 210-231.

Knospe S. 2014. Entlehnungen oder Codeswitching? Sprachmischungen mit den Englischen im deutschen Printjournalismus. Frankfurt am Main. 
Langer N. 1996. Anglizismen in der deutschen Pressesprache. Untersucht am Beispiel von den Wirtschaftsmagazinen 'CAPITAL' und 'DM'. Wettenberg.

Moraldo S.M. 2008. <<kaum @home schreit mein dad rum >>: Internet und die deutsche Sprache oder Anglizismen in Weblogs von Jugendlichen. - Moraldo S.M. (ed.). Sprachkontakt und Mehrsprachigkeit: Zur Anglizismen in Deutschland, Österreich, der Schweiz und Italien. Heidelberg: 107-133.

Onysko A. 2007. Anglicisms in German: Borrowing, lexical productivity, and written codeswitching. Berlin.

Onysko A. 2009. Divergence with a cause? The systematic integration of anglicisms in German as an indication of the intensity of language contact. - Pfalzgraf F. (ed.). Englischer Sprachkontakt in den Varietäten des Deutschen. English in contact with varieties of German. Frankfurt am Main: 53-74.

Plümer N. 2000. Anglizismus - Purismus - Sprachliche Identität: Eine Untersuchung zu den Anglizismen in der deutschen und französichen Mediensprache. Frankfurt am Main.

Pulcini V., Furiassi C., González F.R. 2012. The lexical influence of English on European languages: From words to phraseology. - Furiassi C., Pulcini V., González F.R. (eds.). The anglicization of European lexis 2012. Amsterdam: 1-24.

Sanchez-Stockhammer C. 2012. Hybridization in language. - Stockhammer W.P. (ed.). Conceptualizing cultural hybridization 2012. Heidelberg: 133-157.

Schäfer W. 2002. Von Handys und Erbex: Zur Diskussion um Anglizismen im heutigen Deutsch. - Deutsch als Fremdsprache 39: 75-71.

Scherling J. 2013. Holistic loanword integration and loanword acceptance: A comparative study of anglicisms in German and Japanese. - AAA [= Arbeiten aus Anglistik und Amerikanistik] 38: 37-51.

Steffens D. 2003. Nicht Nur Anglizismen... Neue Wörter und Wendungen in unserem Wortschatz. - Sprachreport 4: 2-9.

Yang W. 1990. Anglizismen im Deutschen: am Beispiel des Nachrichtenmagazins Der Spiegel. Tübingen. 